\title{
INTERNATIONAL BUSINESS WEEKS - FROM CHALLENGE TO OPPORTUNITY
}

\author{
Martina Chalupová ${ }^{\bowtie}$, Martina Černá ${ }^{2}$, Martin Prokop ${ }^{3}$ \\ ${ }^{1 \bowtie}$ Department of Economic Studies, College of Polytechnics Jihlava, Tolstého 16, 58601 Jihlava, Czech Republic, + 420567141111 , \\ martina.chalupova@vspj.cz \\ ${ }^{2}$ Department of Social Works, College of Polytechnics Jihlava, Czech Republic \\ ${ }^{3}$ Department of Mathematics, College of Polytechnics Jihlava, Czech Republic
}

\begin{abstract}
Highlights
- Internationalisation is an important item for students and for institution of higher education

- The most significant barrier of the student mobilities at CPJ appears to be higher cost sensitivity

- Cooperation of IBW network members on the researches from different fields might upgrate the project
\end{abstract}

\section{Abstract}

Article aims to analyse impact of project activities called International Business Weeks (IBW) on outgoing student mobilities at the College of Polytechnics Jihlava. The IBW network was established by University Paris 13 in France and Leuven University College in Belgium (now University College Leuven-Limbourg) 17 years ago to encourage finance/business students to apply for international mobility. The network of European business colleges/universities now contains 15 universities or colleges, College of Polytechnics in Jihlava (CPJ) joined it in 2008. The main goal of the paper is to evaluate the effect of IBW on Erasmus mobility at CPJ. Analysis of the data from CPJ information system shows that this impact has weakened gradually. The data also proved that the interest in IBW among CPJ students is stagnating. Partial goal of the article is to suggest solutions for the projects' revitalization. One of the conclusions is that there is a need for qualitative research among the students about their motivations and obstacles of international mobility, with focus on the psychological profile of the students.

\section{Keywords}

International Business Week, College of Polytechnics Jihlava, network of universities/colleges, mobility, internalization, correspondence analysis

Chalupová M., Černá M., Prokop M. (2016) "International Business Weeks - From Challenge to Opportunity", Journal on Efficiency and Responsibility in Education and Science, Vol. 9, No. 2, pp. 31-36, online ISSN 1803-1617, printed ISSN 23362375, doi: 10.7160/eriesj.2016.090201.

\section{Introduction}

Internationalisation represents a central focus of higher education institutions worldwide, it can be defined as "the process of integrating an international, inercultural, or global dimension into the purpose, functions or delivery of postsecondary education" (Knight, 2015). Teichler (2004) observed three main areas of learning and research related to internationalisation: knowledge transfer, international education and research and cross-border communication. International activities of universities and colleges expanded dramatically in volume, scope, and complexity over the past 20 years (Brooks, Walters, 2013; deWit, 2011; Pesik, Gounko, 2011). Tertiary institutions established various strategies of internationalisation: academic programmes (exchange programmes, cross-cultural training, joint/double degree programs, visiting lectures and other), research and scholarly collaboration (research projects and agreements, exchange programmes), extra-curricular, such as students associations and external relations (domestic and crossborder) (Maringe, Foskett, 2013; Knight, 2008). In the Czech context internationalisation is mainly understood as student and staff mobility and an aspect of quality enhancement (Janebová, 2009; Mertová, 2013).

One of the latest researches among European universities with the focus on internationalisation carried out by European University Association in 2013 showed priorities in higher education institution internationalisation - majority of respondents (30\%) wanted to attract students from abroad, 19\% chose internationalisation of learning and teaching, 10\% saw as a priority strategic research partnerships. No institution chose staff mobility and capacity-building of partners in developing regions as the top priority, and only small number regard rankings $(5 \%)$ and attraction of international researchers $(4 \%)$ as the most important issue.

The main question with regard to international student mobility is the reason why students go abroad. Teichler (2015) mentions two basic ways of mobility: degree mobility, for an entire study programme and credit mobility, for a half-year or a year (e.g. Erasmus+ Programme). Degree mobility can be considered as vertical, from countries of a quantitatively or qualitatively lower level of provision into those with a higher level. Credit mobility is mainly horizontal (between countries with a similar quality in higher education). The main motivators for students' mobility include enhanced employability by obtaining the best quality education, mastering foreign language or even an intention to emigrate (Altbach, 2016) with emphasis on the role of specific psychological traits (Carlson, 2015). Van Mol's (2013) research on the topic revealed how significantly variable are students' motivations, experiences and outcomes within European countries. He presented the system of factors with the major influence on student mobility, in which students' personal motivations are framed with the global context and macro environment of the students' home country (see Figure 1). 


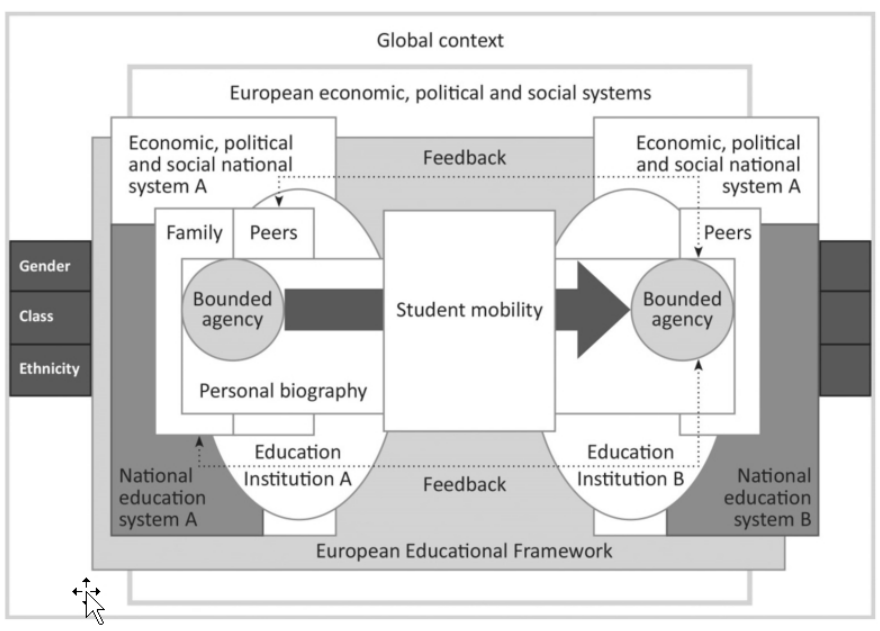

Figure 1: System approach for student mobility dynamics, (source: Van Mol, 2013, p. 153)

According to Teichler (2015) temporary student mobility appears to be effective in preparing students for an increasingly internationalizing environment. His research indicated that the majority of formerly mobile students (but also the majority of employers) believe that internationally experienced students turn out to be superior in number of competences: professional as well as general academic knowledge, communicative skills and personality features. Also, the findings showed that formerly mobile students reached slightly higher positions and a slightly higher income than formerly non-mobile students. The findings varied by field of study as well as by the formerly mobile students' home and host country. As regards field of study, these differences were smaller, as for the country, former Erasmus students from Central and Eastern European countries reported a high professional value for temporary study substantially more often than former Erasmus students from Western European countries.

The complex research among the Czech students (Fischer, Vltavská et al., 2013) showed quite low interest in international mobility. Almost $78 \%$ of respondents (out of the 4664 students from both bachelor and masters study programmes) were not planning to study abroad. On the other hand, almost one third of the students $(31 \%)$ in the bachelor programmes planned to apply for international mobility. Research also revealed higher interest in international experience among students from public universities/colleges. Students in the Czech Republic see financial costs as the biggest obstacles in international mobility. Social selectivity of international student mobility is sufficiently documented also in other EU countries, Lörz et al. (2015) assumes that mechanism underlying this pattern of inequality is not sufficiently studied. The other major barrier of the Czech students is fear of losing job and separation from a partner, children or friends. On the contrary, the lowest barrier is the capacity of a mobility program or problems with the recognition of studies, which decreased significantly (Fischer, Vltavská et al., 2013). Research by Šmídová (2015) indicated that Czech students expect from mobility above all language skills enhancement, personal growth, familiarity of the foreign society and its culture.

The College of Polytechnics Jihlava (CPJ) decided to support its students' interest in international mobilities by joining the network of Universities/Colleges in their project International Business Week (IBW). The aim of this article is to evaluate the project by analysing the quantitative data about the students that attended IBW from February 2009 till May 2015 and of those who applied for Erasmus + programme at the same time. The goal is to prepare an evaluation of the IBW project in terms of its influence on students' willingness to apply for Erasmus mobility. Partial goals are to prepare an evaluation of the IBW project in terms of its influence on students' willingness to apply for Erasmus mobility and to suggest solutions for the projects' expansion and qualitative growth.

The article is an extension of the original article published in ERIE 2014 Conference Proceedings. It presents results of research with quantitative design, analysing data from the CPJ information system. The next chapter presents IBW procedures and the background of the project that has grown in 16 years of its history into vivid international cooperation of European universities and colleges. The following chapter describes the methodology of the analysis of the data. The chapter Results and Discussion summarizes results of the data analysis. In Conclusion the authors specify the need for more research on the topic and include possible evolution of the IBW project at CPJ.

\section{The College of Polytechnics and International Business Week Network}

The College of Polytechnics Jihlava (CPJ) is a public college of a non-university type, offering bachelor study programmes - Electrical Engineering and Informatics, Economics and Management, Midwifery, Health Care and Clinical Social Work. ${ }^{1}$ At the beginning of the academic year 2015/2016 there were 2273 students studying at CPJ. They chose the course of Finance and Management or the course of Travel and Tourism from the study programme Economics and Management, in the study programme Electrotechnics and Informatics the course of Computer Systems or Applied Informatics, in the Health Care the course General Nurse, Midwifery and in the programme Clinical Social Work the course Clinical Social Worker. Students may choose study mobility from 40 partnering institutions in the Erasmus+ Programme (Štěrbová et al., 2015). ${ }^{2}$

International Business Weeks (IBW) network was formed 17 years ago by Belgian Leuven University College (University College Leuven-Limbourg since 2015) and The University of Paris 13 in France. The project reflected the situation in the late 90s: both partners tackled the problem of low interest of finance students in Erasmus mobility. Both universities partnered on the first IBW in Leuven in 1999. In the following years the number of universities/colleges in the network increased (CPJ joined the network in 2008). In the first years all partners came to Leuven, the theme was accountancy, The University of Paris 13 prepared a simulation game. In 2015 there were 15 partnering universities or colleges (National Mining University in Ukraine is not an active member in the present). Each IBW network member organizes a week of student activities, during which students work in international groups on an international business case, the central theme is international business. The main objective of IBW is to let students feel they can cooperate in English with fellow students on business or financial topics in an international context and in that way encourage them to apply

$1 \quad$ From 2014/15 a new Master's degree programme was awarded accreditation as Community Care in Midwifery within the study programme Specialization in Health Care

$2 \quad$ Students of Health Care and Clinical Social Work study programmes have other possibilities for studying abroad than students of Economics and Management. These programmes are quite new (f.e. programme Clinical Social Work started in 2013/14). 
for study abroad (Chalupová, Prokop, 2014).

Three partners (the University of Paris 13, University College Leuven-Limbourg (UCLL) and the Rotterdam University of Applied Sciences) organise IBW twice a year. Universities in Rotterdam and Leuven also offer International Weeks that are specialised in marketing, personal management or accounting, IBA Kolding organises ICT and Marketing Week and UCLL offers also International Weeks for healthcare and social works students. The College of Polytechnics Jihlava cooperates with The Institute of Technology and Economics in České Budějovice and the institutions organise IBW only once in 2 years (the same situation is in Finland with 2 partnering universities - The Lahti University of Applied Sciences and Satakunta University. In the academic year 2014/15 the network offered 13 IBWs (see Table $1)$.

\begin{tabular}{|c|c|c|c|}
\hline Country & $\begin{array}{l}\text { University/ } \\
\text { College }\end{array}$ & IBW Topic & Semester \\
\hline $\begin{array}{l}\text { Portugal, } \\
\text { Setúbal }\end{array}$ & $\begin{array}{l}\text { The Polytechnic } \\
\text { Institute of } \\
\text { Setúbal }\end{array}$ & Entrepreneurship & Winter \\
\hline France, Paris & $\begin{array}{c}\text { The University of } \\
\text { Paris } 13\end{array}$ & $\begin{array}{c}\text { International } \\
\text { Economical } \\
\text { Simulation } \\
\end{array}$ & Winter \\
\hline $\begin{array}{l}\text { Netherlands, } \\
\text { Rotterdam }\end{array}$ & $\begin{array}{l}\text { The Rotterdam } \\
\text { University of } \\
\text { Applied Sciences }\end{array}$ & Risk Management & Winter \\
\hline $\begin{array}{l}\text { Belgium, } \\
\text { Leuven }\end{array}$ & $\begin{array}{l}\text { University College } \\
\text { Leuven-Limbourg }\end{array}$ & Business Simulation & Winter \\
\hline $\begin{array}{l}\text { Denmark, } \\
\text { Kolding }\end{array}$ & $\begin{array}{c}\text { International } \\
\text { Business Academy }\end{array}$ & $\begin{array}{c}\text { Financial and } \\
\text { Management Case } \\
\text { Study }\end{array}$ & Summer \\
\hline $\begin{array}{l}\text { Finland, } \\
\text { Lahti }\end{array}$ & $\begin{array}{c}\text { The Lahti } \\
\text { University of } \\
\text { Applied Sciences }\end{array}$ & $\begin{array}{c}\text { Financial and } \\
\text { Management Case } \\
\text { Study }\end{array}$ & Summer \\
\hline $\begin{array}{c}\text { Czech } \\
\text { Republic, } \\
\text { Jihlava }\end{array}$ & $\begin{array}{c}\text { The College of } \\
\text { Polytechnics } \\
\text { Jihlava }\end{array}$ & $\begin{array}{c}\text { Financial and } \\
\text { Management Case } \\
\text { Study }\end{array}$ & Summer \\
\hline $\begin{array}{l}\text { France, } \\
\text { Paris }\end{array}$ & $\begin{array}{c}\text { The University of } \\
\text { Paris } 13\end{array}$ & $\begin{array}{l}\text { Communiciation } \\
\text { Case Study }\end{array}$ & Summer \\
\hline $\begin{array}{l}\text { Belgium, } \\
\text { Leuven }\end{array}$ & $\begin{array}{c}\text { Leuven University } \\
\text { College }\end{array}$ & Banking Simulation & Summer \\
\hline Latvia, Riga & $\begin{array}{c}\text { Banku } \\
\text { Augustskola }\end{array}$ & $\begin{array}{c}\text { Financial Case } \\
\text { Study }\end{array}$ & Summer \\
\hline $\begin{array}{l}\text { Poland, } \\
\text { Wroclav }\end{array}$ & $\begin{array}{c}\text { Wroclaw School } \\
\text { of Banking }\end{array}$ & Project Management & Summer \\
\hline $\begin{array}{l}\text { Netherlands, } \\
\text { Rotterdam }\end{array}$ & $\begin{array}{l}\text { The Rotterdam } \\
\text { University of } \\
\text { Applied Sciences }\end{array}$ & $\begin{array}{c}\text { Financial Case } \\
\text { Study }\end{array}$ & Summer \\
\hline $\begin{array}{c}\text { Germany, } \\
\text { Zweibrücken }\end{array}$ & $\begin{array}{c}\text { The University of } \\
\text { Applied Sciences } \\
\text { Kaiserslautern }\end{array}$ & Business Simulation & Summer \\
\hline
\end{tabular}

Table 1: IBW Network Offer for Academic Year 2014/15, 2016 (source processed by the authors)

The exact dates of each International Business Week are discussed and announced before the start of the next academic year by official IBW representatives from each partnering university/college. Commonly they are lecturers who are also responsible for organizing IBW in their institutions. The general agreement is that during the IBW each incoming student is granted accommodation for 4 nights, local transport costs coverage and food (4 breakfasts, 4 lunches and 1 dinner), students must pay for the transportation to IBW from their home country. The home university transfers the participation fee for each of the outgoing students to the organizing university (varies from 200 to 245 EUR per person). Each IBW lasts at least 5 working days (Monday till Friday), students work in international groups on a business/finance case. In order to get different nationalities together, partnering institutions can send no more than 5 students to every business week. If there are still places available (just before application deadline), higher student numbers can be discussed. IBW is meant for finance and/or business students. The sending university/college is responsible for the students' selection (by means of interviews, grades, motivation letters or CVs) (Chalupová, Prokop, 2014).

It is recommended that students are accompanied by a lecturer of their home university. Preferably, the lecturer is integrated in the program as a coach, his or her duties include:

- Ensuring the quality of students' presentations - with topics such as basic facts about the home country, city and own university.

- Participation, enthusiasm and cooperation during the business week.

- Punctuality of the students.

- Solution and presentation of the business case.

- Individual end report in English (reflection on the week).

Students that meet the IBW standards receive a common validation paper with recognition of all partner universities involved in the network. Participation is validated by the sending university, students receive 2 credits (Chalupová, Prokop, 2014).

\section{Materials and Methods}

The data about the students who have attended IBW and Erasmus mobility were extracted from CPJ's information system. It included information about the semester in which student attended IBW, student's study programme and whether he or she attended internal (in Jihlava) or international IBW (no information about specific university/college or country). The list was then compared with the list of Erasmus mobility participants, sorting data in 3 categories: students that attended only IBW, but did not apply for Erasmus mobility, students that went on Erasmus mobility after attending IBW, and students that attended IBW after their Erasmus mobility. First CPJ students attended IBW in the summer semester 2008/09, since then 290 of them from study courses Finance and Management and Travel and Tourism took part in the project.

Data have been processed with correspondence analysis (CA), a multivariate statistical technique. The method provides a means of displaying or summarizing a set of data in two-dimensional graphical form (Nenadić, Greenacre; 2007). All data should be nonnegative and on the same scale for CA to be applicable, it treats rows and columns equivalently. It is traditionally applied to contingency tables; the method decomposes the chi-squared statistic associated with this table into orthogonal factors. The idea in CA is to reduce the dimensionality of a data matrix and visualize it in a subspace of low-dimensionality, commonly twoor three dimensional. The CA solution was shown by Blasius and Greenacre (1994) to be neatly encapsulated in the singularvalue decomposition (SVD) of a suitably transformed matrix. For the process, first divide the $I \times J$ data matrix, denoted by $N$, by its grand total $\mathrm{n}$ to obtain the so-called correspondence matrix $P=N / n$. Let the row and column marginal totals of $P$ be the vectors $r$ and $c$ respectively, that is the vectors of row and column masses, and $D_{r}$ and $D_{c}$ be the diagonal matrices of these 
matrices (Hebák et al., 2007). The computational algorithm to obtain coordinates of the row and column profiles with respect to principal axes, using the SVD, starting with matrix of standardized residuals (1) - (2) as follows:

1. Calculate the matrix of standardized residuals:

$$
S=D_{r}^{-\frac{1}{2}}\left(P-r c^{T}\right) D_{c}^{-\frac{1}{2}}
$$

2. Calculate the SVD:

$$
S=U D_{\alpha} V^{T} \text { where } U^{T} U=V^{T} V=I
$$

3. Principal coordinates of rows:

$$
F=D_{r}^{-\frac{1}{2}} U D_{\alpha}
$$

4. Principal coordinates of columns:

$$
G=D_{c}^{-\frac{1}{2}} V D_{\alpha}
$$

5. Standard coordinates of rows:

$$
X=D_{r}^{-\frac{1}{2}} U
$$

6. Standard coordinates of columns:

$$
Y=D_{c}^{-\frac{1}{2}} V
$$

The total variance of the data matrix is measured by the inertia (see, e.g., Hebák et al.; 2007), which resembles a chi-square statistic but is calculated on relative observed and expected frequencies:

7. Inertia $=\varphi^{2}=\sum_{i=1}^{I} \sum_{j=1}^{J} \frac{\left(p_{i j}-r_{j} c_{j}\right)^{2}}{r_{i} c_{j}}$

The rows of the coordinate matrices in (3)-(6) above refer to the rows or columns, as the case may be, of the original table, while the columns of these matrices refer to the principal axes, or dimensions, of the solution. Notice that the row and column principal coordinates are scaled in such a way that $F D_{r} F^{T}=G D_{c} G^{T}=D_{\alpha}^{2}$, i.e. the weighted sum-of-squares of the coordinates on the the kth dimension (i.e., their inertia in the direction of this dimension) is equal to the principal inertia (or eigenvalue) $\alpha_{k}^{2}$, the square of the k-th singular value, whereas the standard coordinates have weighted sum-of-squares equal to 1: $X D_{r} X^{T}=Y D_{c} Y^{T}=I$. The implementation of the algorithm follows Blasius and Greenacre (1994). The graphical representation of results from $\mathrm{CA}$ is commonly done with so-called symmetric maps. In that case, the row and column coordinates on each axis are scaled to have inertias equal to the principal inertia along that axis: these are the principal row and column coordinates.

There has also been a contingency table constructed; Pearson's Chi-square test of independence was counted in order to confirm or disapprove the relation between variables. If the p-value calculated by means of the $\chi^{2}$ test (Pearson Chi-square test) is lower than the selected level of significance $\alpha=0.05$, null hypothesis is rejected. The analysis was carried out using SPPSS programmes.

\section{Results}

The data obtained from the CPJ information system show that since academic year 2007/2008 up till 2014/15 the total number of 389 CPJ students had attended Erasmus Mobility Programme, 290 students had attended IBW. The network offers 13 IBWs in an academic year, which can be attended by 65 students from the

\begin{tabular}{|c|c|c|c|c|c|}
\hline \multicolumn{2}{|r|}{ స్తి } & $\underset{\sim}{\stackrel{0}{N}}$ & $\stackrel{9}{=}$ & $\underset{\infty}{\infty}$ & ঐ্ণ \\
\hline \multirow{8}{*}{ لَّ } & $\frac{n}{\frac{n}{5}}$ & $\hat{m}$ & ন & రิ & రె \\
\hline & $\underset{⿱ 亠 m}{\stackrel{\Xi}{d}}$ & ભે & 그 & 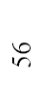 & 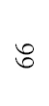 \\
\hline & 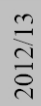 & $\stackrel{m}{m}$ & I & in & in \\
\hline & $\underset{\equiv}{\stackrel{N}{\Xi}}$ & nn & $a$ & 广 & શે \\
\hline & $\begin{array}{l}\vec{F} \\
\text { ㅇ } \\
\text { ㅇ }\end{array}$ & $尹$ & $\stackrel{0}{ }$ & $\vec{n}$ & $\stackrel{\curvearrowright}{\partial}$ \\
\hline & 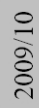 & nै & $a$ & 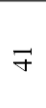 & 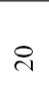 \\
\hline & $\begin{array}{l}\stackrel{2}{0} \\
\infty \\
\delta \\
\delta\end{array}$ & in & $\stackrel{0}{-}$ & ๖ & $\ddot{\sim}$ \\
\hline & 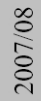 & $\ddot{\sim}$ & 工 & $m$ & 0 \\
\hline \multicolumn{2}{|c|}{$\begin{array}{l}\frac{5}{0} \\
\frac{0}{0} \\
\frac{0}{0} \\
0 \\
0 \\
0 \\
0\end{array}$} & 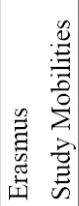 & 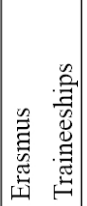 & 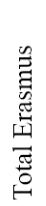 & 畐 \\
\hline
\end{tabular}
partnering institution (as it was mentioned earlier, university/ college can send no more than 5 students to every business week, higher student numbers must be discussed). In 2013/14 CPJ was sending the highest number of students for the IBW (66 in total).

Table 2: Outgoing student mobilities at CPJ, 2016 (Source: CPJ Information System, processed by the authors)

As it is apparent from Tab. 2, the number of students interested in IBW changed significantly in 2011 (from 29 to 59 the next year). By 2011 CPJ had supported each student with 2.500 CZK (100 EUR at that time) to help finance their participant fee. In 2012 each student that has represented CPJ on the IBW successfully also received upon their arrival additionally 3000 CZK in the form of scholarship. In 2013 this support rose up to 5.000 CZK and it covered $90 \%$ of the students' costs (they had to pay for their transportation). This academic year could have set the record, as the total number of students who signed up for IBW was even higher - in the summer semester of 2013/14 the National Mining University in Dnipropetrovsk had to postpone its international week due to the political situation and therefore 5 CPJ students did not leave for IBW in Ukraine. In 2014/15 most organisers raised their fees up by $10 \%$ and in this year the interest of the students for the IBW dropped slightly. This 
indicates that financial costs play a major role in the decision making process of the CPJ students for international mobility. On the other hand, it is obvious that IBW mobilities costs ${ }^{3}$ for $\mathrm{CPJ}$ are rising and can be viewed as a high finacial burden with low effect on the main goal (the support of Erasmus mobilities).

Results in Tab. 3 show, that IBW fulfilled its purpose (the support of Erasmus Programme) best in academic year 2009/10, when almost one third of those who attended IBW decided to apply for Erasmus mobility.

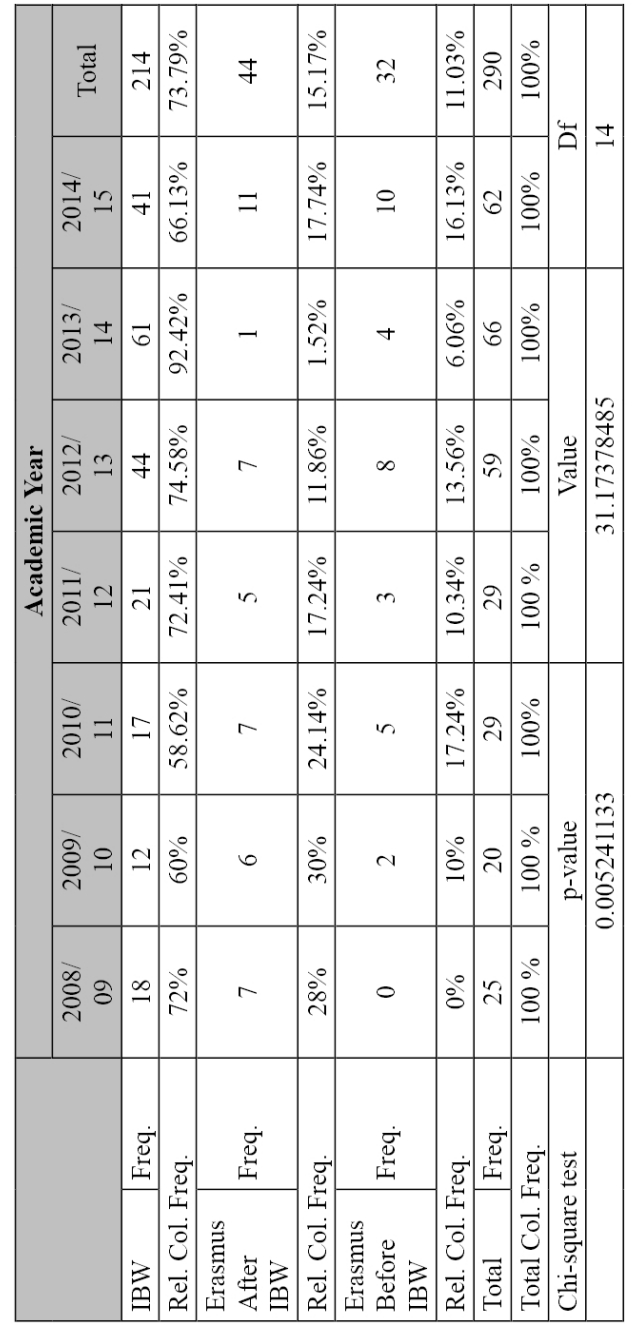

Table 3: Attendants of IBW and Erasmus, 2016 (source: CPJ Information System, own calculation)

Data in Tab. 3 also show that the number of students interested in IBW rose (from 25 in 2008/09 up to 66 in 2013/14), its impact on Erasmus mobility has weakened (the worst results were in 2013/14, when only 1 out of 66 students who attended IBW applied for Erasmus mobility). In the last academic year the trend was different - the number of IBW attendants slightly dropped (62 students), but the number of those who applied for Erasmus mobility rose (11 students). Relatively high number of students over the years who have attended IBW after their Erasmus stay can be viewed as a disadvantage, these students shouldn't be a target group for the project. However, it is an understandable and positive fact that the students who returned from their studies or traineeships abroad apply for IBW.

$3 \quad$ In academic year 2014/2015 the financial support for each student was 5000 CZK.. With 62 students attended IBW in that year, it represents $310000 \mathrm{CZK}$. The accompanying lecturers are supported by Erasmus+ programme.

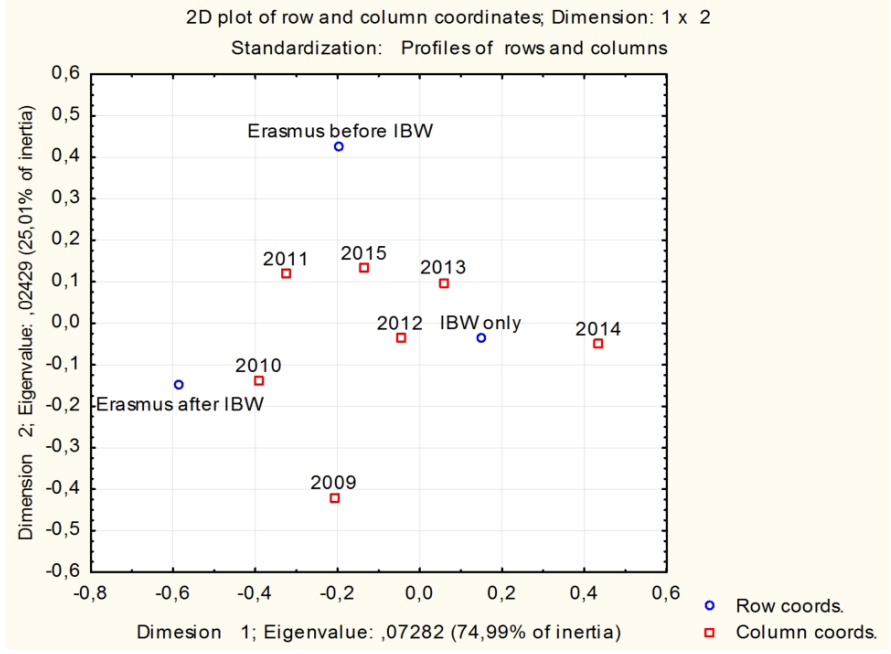

Graph 1: Correspondence analysis - CPJ student outgoing mobilities, 2016 (source: own calculation)

Correspondence map (Graph 1) shows that points representing values of individual variables that are the nearest appear together the most frequently. Occurence of outlier means that this value is connected the least frequently in connection with all values of the second variable. Graph 1 shows (as well as the results from the Tab. 3) that the students who attended IBW haven't decided to sign up for the Erasmus+ Programme frequently in the last 4 years. The proportion of students with no Erasmus experience (who attended IBW) exhibits greater variability and the plot is located aside, it illustrates that this situation does not have the long-term downward or upward trend.

\section{Discussion}

IBW was a challenge at the beginning - it was necessary to present it to the students as an opportunity that they should take. The rising number of the attendants up till the current level signals that the communication with the students was successful. The research on quality of information students receive about the international mobilities including IBW indicates that it is of a high level - almost $100 \%$ of Travel and Tourism and Finance and Management students knew about these possibilities to study or work abroad (Chalupová, 2014). As the current research shows, the most serious barrier in mobilities at CPJ might be the financial limitations of the students, which was also an outcome of the research of Fischer, Vltavská et al. (2014) or Lörz et al. (2015). Also, the trend of the IBW mobilities costs for $\mathrm{CPJ}$ is rising and the effect on Erasmus mobilities remains very low (the minor positive tendency was observed in 2014/15). To support the continuation of IBW activities it is necessary to demonstrate another benefits, for example networking and consequent cooperation with IBW partners on projects and in the field of research.

\section{Conclusion}

Based on the results we can summarize that IBW project in the present does not influence CPJ students significantly in their decision to apply for Erasmus mobility. In academic year of 2013/14 only 1 student out of 30, who attended IBW, applied for Erasmus mobility. The project therefore isn't currently fulfilling its purpose. We suggest that the criteria for evaluation of IBWs have to be set more broadly. They should reflect all possible benefits of cooperation with members of IBW network. It can be viewed positively that in 2015/16 students from the study programme Electrotechnics and Informatics and Clinical Social Work will have an opportunity to join project activities similar to IBW, but specialised in the case studies from their field of 
study. This opportunity was offered from the members of the IBW network. Also, it would be interesting to analyse if the IBW project has effected the number of incoming students (if the number of students from the IBW network members that come to study at CPJ is significantly higher than from other partnering universities/colleges).

As the research indicated, financial costs of mobility may be considered as the major factor. Another important factor that should be tested is the personal profile of the applicants, because it may play a significant role, as it is shown in Van Mol's (2013) scheme. The next research should have a qualitative design, preferably in-depth interviews. The topic of this research should be oriented on the motivations and barriers that students from underprivileged families have to face when deciding for international mobilities. CPJ is a regional college attracting mainly the students from Vysočina Region. The incomes of the families in this region belong traditionally to the lowest in the Czech Republic (Majerová et al., 2011).

We can expect that the positive trends in mobilities of CPJ students that have been observed (interest in IBW and Erasmus + training ships) may stop in the future. Students' willingness to spend time abroad may be affected by their safety concerns that arose after the terrorist attacks in Paris in 2015 and Brussel in 2016. As this topic is very recent, there is a research gap in this field. Such research could have international character, members of the IBW network could be involved. Cooperation of the IBW network members on the researches from different fields might upgrade the project.

\section{References}

Altbach, P.G. (2016) Global Perspectives on Higher Education, Baltimore: Johns Hopkins University Press. ISBN 978-1-42141926-8.

Blasius, J. and Greenacre, M., J. (1994) Computation of Correspondence Analysis. In: Greenacre, M.J., Blasius, J. (eds.), Correspondence Analysis in the Social Sciences, pp. 53-75. Academic Press, London. ISBN-13: 978-0121045708.

Brooks, R. and Walters, J. (2013) Student mobilities, migration and the internationalization of higher education. Basingstoke: Palgrave Macmillan. ISBN 978-0-230-30558-8.

Carlson, B. (2015) Globalising teaching and learning in Indigenous Studies [online]. Artlink, Vol. 35, No. 2, Jun 2015: 80-82. Availability: $<$ http://search.informit.com.au/document Summary; $\mathrm{dn}=251120684062492 ;$;es=IELAPA $>$ ISSN: 07271239. [19 May, 2016].

Chalupová, M. and Prokop, M. (2014) International Business Week - Impact on Student Mobility. In Efficiency and Responsibility in Education (ERIE) 2014. HOUŠKA, Milan. Praha: ČZU. 2014. s. 241-247. ISBN 978-80-213-2468-8.

Chalupová, M. (2014) Internacionalizace - cesta ke zvyšování konkurenceschopnosti Vysoké školy polytechnické Jihlava. In Rojík, S. 6. mezinárodní vědecká konference Konkurence 2014. VS̆PJ. 2014. s. 52-60. ISBN 978-80-87035-91-7.

Fischer, J. and Vltavská, K. (2013) EUROSTUDENT V: Základní výsledky šetření postoju a životních podminek studentů vysokých škol v České republice, Praha: Ministry of Education, Youth and Sports, Available At: http://www.zkola.cz/studenti/ clankyaodkazy/Documents/zaverecna_zprava_eurostudent_v. pdf [3 February, 2016].

Hebák, P., Hustopecký, J. and Malá, I. (2007) Vicerozměrné statistické metody. Praha: Informatorium, spol. s.r.o. ISBN 97880-7333-036-1.
Janebová, E. (2009) Vedení internacionalizace vysokých škol, Studia paedagogica, Vol. 14, No. 2. DOI: 10.5817/SP2013-4-7. Knight, J. (2008) Higher Education in Turmoil. The Changing World of Internationalization. Rotterdam: Sense Publishers. ISBN: 978-90-8790-522-4.

Knight, J. (2015) Updated definition of internationalization. International higher education, (33). Retrieved from: http:// ejournals.bc.edu/ojs/index.php/ihe/article/viewFile/7391/6588. [3 February, 2016].

Lörz, M., Netz, N. and Quast, H. (2015) Why do students from underprivileged families less often intend to study abroad?Higher Education, Vol. 43, p. 1- 22. Springer Netherlands. ISSN 1573174X. DOI: 10.1007/s10734-015-9943-1

Majerová, V., Kostelecký, T., Sýkora, L., Vajdová, Z. and Matoušek, R. (2011) Sociální kapitál a rozvoj regionu. Př́klad Kraje Vysočina. Praha: Grada, 224 p. ISBN 978-80-247-4093-5. Maringe, F. and Foskett, N. (2013) Globalization and Internationalization in Higher Education. Theoretical, Strategic and Management Perspectives', Bloomsbury Academic; Reprint edition. 336 p. ISBN-13: 978-1441177094

Mertová, P. (2013) Higher Education Through a Critical Event Narrative Inquiry: Perspectives From Three Higher Education Systems, Studia paedagogica, Vol. 18, No. 4. DOI: 10.5817/ SP2013-4-7.

Van Mol, C. (2013) Intra-European Student Mobility and European Identity: A Successful Marriage? Population, Space and Place, Special Issue: International Student Migration, Vol. 19, No. 2, pp. 209-222. DOI: 10.1002/psp.1752.

Nenadić, O. and Greenacre, M., J. (2007) Correspondence Analysis in R, with Two- andThree dimensional Graphics: The ca Package. In Journal of Statistical Software. Vol. 20, No. 3, [2015-05-16]. Retrieved from: www.jstatsoft.org/article/view/ v020i03/v20i03.pdf

Pesik, R. and Gounko, T. (2011) Tertiary Education in the Czech Republic: the Pathway to Chase. Compare: a Journal of Comparative and International Education, Vol. 41, No. 6, pp. 735-750. DOI: 10.1080/03057925.2011.573639.

Šmídová, M. (2015) Inernationalization of Higher EducationStudent's Foreign Academic Mobility from the Czech Republic through Data Eurostudent IV, Orbis Scholae, Vol. 9, No.1, pp. 29-54. DOI:10.14712/23363177.2015.71.

Štěrbová, A., Bílkovská, J. and Chalupová, I. (2015) Internacionalizace vzdéláváni na Vysoké škole polytechnické Jihlava 2014 - 2015, Strategie udržitelnosti a rozvoje, Information System CPJ. [16 January, 2016].

Teichler, U. (2015) The Impact of Temporary Study Abroad in Mitchel, R., Tracy-Venture, N., McManus, K. (eds.) Social Interaction, Identity and Language Learning During Residence Abroad Eurosla Monographs Retrieved from: http://eprints. soton.ac.uk/381255/1/EM04tot.pdf\#page $=15 \quad[18$ January, 2016].

Teichler, U. (2009), 'Bologna - Motor or Stumbling Block for the Mobility and Employability of Graduates? ' In Schomburg, H., Teichler, U. (Eds.) Employability and Mobility of Bachelor Graduates in Europe, Rotterdam, Sense Publishers, DOI: 10.1007/978-94-6091-570-3_1

De Wit, H. (2011) Globalisation and Internationalisation of Higher Education. Revista de Universidad y Sociedad del Conocimiento. (RUSC), Vol. 8, Is. 2, pp. 241-248. Retrieved from: http://rusc.uoc.edu/ojs/index.php/rusc/article/view/v8n2dewit/v8n2-dewit-eng, [3 February, 2016]. ISSN 1698-580X. 